\title{
Vote Trading and Electoral Success in Nigerian Democracy
}

\author{
Ilori Oladapo Mayowa
}

Department of Sociology, Faculty of the Social Sciences, Ekiti State University, Ado Ekiti, Ekiti Sate, Nigeria

\begin{abstract}
Democracy is based on the principle of the majority able to choose who leads them in a free and fair context devoid of external interference and political influence. The right to elect a wrong candidate is even part of democracy. The law cannot regulate the legitimate choices that the democratic free will is entitled to make. It chooses what it will. It rejects what it will not choose, or else the democratic free will ceases to be what it fundamentally ought to be, namely "free". Vote trading is a concept in the Nigerian democratic experience. The issue of vote-trading has been in Nigeria's democracy since its inception but became prominent during the present democratic dispensation. Vote buying has been serving as a clog in the wheel of free choice which is the hallmark of a democracy. Unfortunately, not all people that being influenced by vote-buying know what is going on. Some people indulge in the act of vote-trading unknowing. This study which is mainly based on literature and conceptually looked at the influence of vote trading on voter's free choice, the factors that influenced both vote buying and selling, and how it can be curbed. Consequently, past literature, like journals, books, and other publications on vote-trading were considered in this study.
\end{abstract}

Keywords: Votes, Voters, Selling, Buying, Democracy.

\section{INTRODUCTION}

One of the beauties of democracy is the free will to choose at polls (Engelen, 2007) because elections and its sorts serve as one of the avenues of electing leaders in many countries globally (Dauda, Adamu, \& Ahmodu-Tijani, 2019), in other words, the role of election as a precondition to democratization process cannot be under-estimated globally, both in developed and emerging democracies as it offers the freedom of choice but when this is lacking, then democracy is under threat. For several years since the return of democracy in 1999, elections in Nigeria have been bedevilled by various forms of irregularities, namely ballot box snatching, voter inducement, voter harassment, and violent confrontations among rival political groups (Casimir, Omeh, \& Ike, 2013). Recently, vote trading has served as a clog in the wheel of free choice at polling booths. No wonder the 2019 general elections were characterised by vote trading (Dauda et al., 2019). Both local and international elections observers equally attested to the fact that the 2019 general elections were marred with voter intimidation, voter's apathy, vote-rigging, and vote trading among other election malpractices. The 2019 general elections will for many, go down in the history of Nigeria as one of the worst in terms of the widespread nature of the irregularities, especially voter inducement, amid the massive deployment of security agents across the 36 states and the Federal Capital Territory (Punch, 2018).

*Address correspondence to this author at the Department of Sociology, Faculty of the Social Sciences, Ekiti State University, Ado Ekiti, Ekiti Sate, Nigeria; E-mail: mayowadapo77@gmail.com, oladapo.ilori@eksu.edu.ng

E-ISSN: 1929-4409/21
Trading is simply the act of buying and selling goods and services. Trading can also mean an act of exchange of goods and services for money. Trading involves the transfer of goods and services from one person or entity to another often in exchange for money. A trader is a person who is commissioned to buy and sell goods through an exchange and/or charging a commission to do so. Trade is a basic economic concept involving the buying and selling of goods and services, with compensation paid by a buyer to a seller or the exchange of goods or services between parties. Trade can take place within an economy between producers and consumers. (Hayes, 2019).

In the developing world, the political class usually engages in different forms of mobilisation process to gain the hearts of the electorates and this mobilisation process may include the offering of cash, promises, gifts, appointments, and so on to win votes from the electorates. This action from both the political class and the electorates may be termed vote trading (Dauda et al., 2019). Electioneering campaigns in the developing democracies are most times characterised by the high prevalence of vote trading, that is, attempts by political parties to mobilise support by distributing cash and material benefits to the electorates in exchange for support before the election (Bøttkjær, Jensen, \& Justesen, 2016), and the willingness of the would-be voter to exchange the votes for cash. Vote trading is a situation in which a politician is willing and ready to offer an incentive to the would-be voter to influence his/her conscience towards voting for a particular political party or candidate while vote-selling on the other hand is the act of taking incentives (mostly money) from someone who wants you to vote for a 
particular person. Vote trading according to the Oxford Advanced dictionary ( $6^{\text {th }}$ edition), is the distribution of material benefits to an individual voter in exchange for support in a ballot. Vote trading can be said to be a reward or compensation (mostly monetarily), given to a person for voting in a particular way. It is an inducement given to a voter to skew his conscience for voting. Vote trading is one of the methods by political parties and candidates to capture and/or swing votes on Election Day. Vote trading is a widespread phenomenon in Nigeria's democratic process and has been accepted as part of our electoral culture in Nigeria (Sakariyau, Aliu, \& Adamu, 2015), but the act has caused a lot of damages to the electoral processes in the country (Dauda et al., 2019). It is usually viewed as a purely economic exchange in which the voter sells his/her vote to the highest bidder (Onuoha \& Ojo, 2018). Also, the intending buyer (who most times are politicians or their associates), will want the voter to show evidence of voting for his/her party before payment is made. Vote trading has always played a role in Nigeria's electoral processes, but many have been outraged at the apparent brazenness with which party officials have sought to sway voters in recent contests (Onuoha \& Ojo, 2018). According to both local and international election monitoring teams, political agents of both the two (2) leading political parties in the country, openly offered cash for votes in the recent elections conducted in the country. According to a 21year-old voter called Peter; they gave me \#2,500 (\$7) to vote for their candidate, I was happy and collected it because I didn't have any money, they collected our phone numbers and said they will call us in the next morning.

However, expressing its dissatisfaction about the unawesome practice by the politicians and the voters, the Independent National Electoral Commission (INEC), represented by its National Commissioner, Mr. Festus Okoye, speaking at an interactive session with traditional rulers in Osun state, informed the meeting that the Commission has uncovered new methods of vote-trading by both the politicians and the voters. According to him, some people were inducing the voters to release their Permanent Voters Card (PVC) or the Voter Identification Numbers (VIN). He said the intention behind the move was to either stop the owners of the cards from voting or to attempt using the VIN to hack into the Commission's website and preload card readers ahead of the elections.

Consequently, as part of the measures to stem the growing incidence of vote-trading in the electoral processes which is giving the country's electoral fortune a bad image, INEC has introduced some measures to stop vote trading in the electoral process in Nigeria. One of the measures is a partial ban on the use of mobile phones and other photographic devices by voters while in the voting cubicles.

\section{OBJECTIVE OF THE STUDY}

The main objective of this study is to look at the issue of vote trading which has become a trademark name in Nigeria's vote process today. The study will equally look at the forms of vote-trading and its effects on the electoral process.

\section{LITERATURE REVIEW}

In this section, a review of the related literature, like books, journals, and other publications were conducted. This means those contributions and the views of other scholars and newspaper editors on the issue of vote-trading in Nigeria. The review was conducted under the following sub-headings:

\subsection{Forms of Vote Trading.}

\subsubsection{Procurement of Voters Cards}

This is one of how politicians buy votes in Nigeria. This process, in most cases, is unknown to the voters. Politicians here come under the auspices of different empowerment programmes for voters and they (politicians) will request the voters to supply the photocopy of their voters' cards as a pre-condition to assess the benefits attached to such an empowerment programme. It is believed that there are ways in which the Personal Identification Number (PIN) in the voters' cards can be extracted to make it difficult for the INEC card readers to recognise such cards thereby disenfranchising the owner of the card. The overall benefits of empowerment programme is to provide education, employment assistance, health, housing referrals and support services for citizens who are in a disadvantage position. But the recent happenings have shown that these empowerment programmes are being used to buy votes. It is discovered that most of the empowerment programmes are being done very close or during the electioneering campaigns. For instance, during the last presidential election held in February 2019, the Vice President engaged in the distribution of soft loans to traders tagged "Tradermoni" and "Marketmoni" in the country to complement their trading activities. However, this action was misconceived in some quarters, especially the main opposition party in 
the country which alleged the Vice President of votebuying. Consequently, Comrade Timi Frank, a former Deputy National Publicity Secretary of the ruling All Progressive Party (APC) said the Vice President was used by the government in power to commit electoral fraud through the distribution of monetary incentives called "Tradermoni" and "Marketmoni" aimed at sway the conscience of the electorates.

\subsubsection{Sharing of Cash before and during Elections}

Cash sharing before and during elections is one of the major ways of vote-trading in Nigeria. Various denominations of naira (ranging from \#200 to \#1000), depending on the negotiation power, are being brandished and shared by the politicians before and during elections. It is a known fact that the higher the cash you share during the election, the brighter your chance of winning such an election. The phenomenon of money politics in Nigeria is not a new concept, the history of electioneering processes in the country, especially after the independence, was largely influenced by buying and selling of votes (Sakariyau et al., 2015) . No wonder the politicians are always trying to outspend themselves to have a bright chance of winning the election. Vying for political office in Nigeria has now been left for the rich and those at the upper echelon of society due to the huge amount of money involved in the electioneering. Despite various public outcries about this action of politicians and several attempts by INEC to put a stop to this menace, it has yielded little or no result. Electioneering in Nigeria has been commercialised to the extent that money has become a dominant and a determinant factor. The poor are likely to be victimised by vote-buying because their limited means make them susceptible to material inducement, including offer of basic commodities or modest amounts of money, which is a simple economic exchange. However, one cannot rule out the possibility that poverty in Nigeria is deliberate by the political class to enable them (the political class) to skew voting in their favour via giving the electorates stipends during elections. In vote-buying transactions, voters are usually offered money, commodities such as food or clothing. Though the electoral act regulates political finance in the country. According to the Nigerian Electoral Act, 2010, Article 130, " A person who: (i) corruptly by himself or by any other person at any time after the date of an election has been announced, directly or indirectly gives or provides or pays money to or for any person to corruptly influence that person or any other person for the purpose to vote or refrain from voting at such election, or on account of such person or any other person having voted or refrained from voting at such election or (Damm \& Gorinas) being a voter, corruptly accepts or takes money or any other inducement during any of the period stated in paragraph (i) of this section, commits an offence and is liable on conviction to a fine of \#100,000.00 or 12 months imprisonment or both. While vote trading in Nigeria is subject to punishment, the attainment of compliance to this legal provision remains a challenge. In vote-buying transactions in Nigeria, voters are usually offered cash, commodities (such as food or clothing) or jobs. In some cases, towns and communities are offered projects to skew their votes. In the latest and previous Nigerian elections, the most common inducement was the cash of about \#500 or about $\$ 4$. But the median price of a vote payment rose between the 2003 and 2007 elections, from \#1750 to $\# 2250$, largely because the proportion of large payments (\#10,000 or more per vote) has increased over time (Bratton, 2008). During the last gubernatorial election in Ekiti state in 2018, the two major political parties were heavily involved in sharing money before and during the election. The amount shared ranged from \#3,000 to \#15,000 depending on the polling booth, the town, or the personality sharing the money. Also, during the 2019 Presidential election in the state, the story of sharing money for a vote was not different. The Punch newspaper $\left(14^{\text {th }}\right.$ July 2018) as its headline captioned "Ekiti Election: Parties Engage in Preelection Day Vote Buying", posited that political parties have been going from house to house targeting voters and inducing them with a sum of $\# 4,000$. According to the daily, politicians have started distributing money to influence voters to cast their votes for their candidates in the election. Adedokun Seyi (Saraha Reporter, 2018) stated that the conquest of Fayemi in the gubernatorial election in Ekiti state in 2018 was not as a result of people's love for his party, APC or him and even if the PDP had won, it wasn't for the trust they have in it but the game was rolling, changing and shaking according to how the line of monetary cacophony stretches.

\subsubsection{Distribution of Stomach Infrastructural Commodities}

Stomach infrastructure is a new concept in Nigeria's political sphere. Stomach infrastructure is the distribution of items and/or commodities which are basically for feeding purposes. This new concept which is all about the survival of the citizens is aimed at inducing potential electorates to vote for a particular candidate(s) during an election (Stober, 2016). Stomach infrastructure is a process based on the 
principle of politicians making provisions for hand-outs for the electorates to fill their stomachs primarily before and/or during elections. Stomach infrastructure concentrates more on the citizen's immediate needs, which may include: empowerment programmes for unemployed for the citizens, cash to the aged, health service delivery to assist the poor, agricultural facilities for the rural poor farmers, skill acquisition centres for the poor unskilled citizens, loan grants for seed capital to enable them to take off in little measure, direct food relief for the poorest of the poor, borehole in rural communities to solve water scarcity problems, the establishment of small-scale cottage industries in the villages where the rural community can work and also acquire experience on how to produce minor things (Stober, 2016).

\subsubsection{Using of Social Amenities}

Building of amenities, especially where not needed and when not needed have been another factor influencing the electorates during elections, and in most cases, the amenities are white elephant projects which may never be completed, but the purpose is to influence the voting pattern of the citizens residing in the areas where such projects are cited. Nearly every community in the Nigerian state is deficient in terms of good infrastructural development and this has made the demand for infrastructural development very high and even context among the communities in some instances. The political class always capitalise on the high demand for infrastructural development as an exchange for a vote. There are instances where the government will embark on building a project to gain votes from the electorates and as soon as elections are over, such a project will be abandoned and become moribund.

\subsection{Factors Responsible for Vote Trading}

\subsubsection{Poverty}

The high prevalence of poverty in developing nations, Nigeria inclusive has made the political class always engage in vote trading to win votes from the electorates, especially the poor. It is believed that poor citizens, those at the lower ebb of the societal structure, and the low-income earners are more vulnerable to vote-trading than the rich citizens and the elites (Stokes, Dunning, Nazareno, \& Brusco, 2013). The poor citizens usually jettison future programmes benefits because future rewards are not certain and not sure than what they can see and collect now (Stokes et al., 2013). Poverty can be seen as an essential channel of vote-trading in developing economies and it has constituted a major threat to the way electoral democracy runs (Jensen \& Justesen, 2014). Poverty in Nigeria from all indications is a deliberate handiwork of the Nigeria's political class and the elites; so that the electorates will always come for the crumbs during the electioneering period, poverty acts as a clog in the when of the country move to a genuine democracy (Onwuama, 2019). Poverty on political choices is a social problem and a major threat to Nigeria's democracy. This menace had had a devastating effect on the democratic process and democratic benefits because it has resulted in electoral manipulation, violence, and underdevelopment by the political class and has consequently resulted to the agenda of stomach infrastructure and violence in winning elections (Onwuama, 2019).

\subsubsection{Quest for Political Representation}

The continuous agitation for political representation has forced both the political class and the citizens to engage in the act of vote trading. Political representation is the activity of making citizens present in public policy-making processes when politicians perform their duties in the best interest of the people they represent (Wikipedia, 2019). Nigeria is a multiethnic and multi-religious state, hence, every ethnic group and every faith wants to be adequately represented in the political cycle, to be involved and participate in shaping the decision-making of the government. Knowing fully well that their voices, opinions, and perspectives will be taken care of (Dovi, 2006). Political representation is based on the principle of political class speak, advocate, symbolise, and act on behalf of the constituencies they represent. The Nigerian citizens believe that political representation will provide political leverage for them and give them a voice in terms of social and human development. Political representation has been identified as a means by which the democratic principle of giving citizens a voice in large states is realised (Weßels, 2015). Some of the benefits of political participation include improved governance, greater social cohesion, improved quality of service, projects and programmes, greater capacity building and learning.

\section{CONCLUSION}

Vote trading is absurd, illegal, and unconstitutional and must be stopped by any means possible, if not, the choice of political leadership in the country will no longer be based on merit or popular choice, but by 
highest bidders for votes irrespective of a candidate's qualification, pedigree, and quality.

\section{RECOMMENDATIONS}

Below are some of the recommendations made on the issue of vote-trading in Nigerian society:

i. All government organs in connection with the election (INEC, Police, and other security agents) should work in harmony to ensure that the menace of vote trading is discouraged before and during elections.

ii. INEC should ensure that the political parties adhere to the approved electioneering funds and that the parties do not exceed the limit approved.

iii. The Executive arm of government should establish a special court for the trial of electoral offenders.

iv. There should be the installation of Closed Circuit Televisions (CCTV) around polling booths in the country to monitor the activities of INEC officials, the security agents, and the voters during elections.

v. Any INEC official or security agent who compromises the rules and regulations guiding the conduct of the elections should be brought to book.

vi. Government should prioritise job creation and job sustenance to reduce poverty and improve the standard of living

\section{REFERENCES}

Bøttkjær, L. Thorn., Jensen, P. Sandholt., \& Justesen, M. Kamp. (2016). Buying the Votes of the Poor: How the Electoral System Matters. Paper Presented at the The 10th ECPR General Conference.
Bratton, Michael. (2008). Vote Buying and Violence in Nigerian Election Campaigns. Electoral Studies, 27(4), 621-632. https://doi.org/10.1016/j.electstud.2008.04.013

Casimir, Ani., Omeh, Emma., \& Ike, Chinedu. (2013). Electoral Fraud in Nigeria: A Philosophical Evaluation of the Framework of ELECTORAL Violence. Open Journal of Political Science, 3(04), 167. https://doi.org/10.4236/ojps.2013.34023

Damm, A. Phil., \& Gorinas, Cedric. (2013). Deal Drugs Once, Deal Drugs Twice: Peer Effects on Recidivism from Prisons. Essays on Marginalization and Integration of Immigrants and Young Criminals-A Labor Economics Perspective. Aarhus University.

Dauda, Muritala., Adamu, Abdullahi., \& Ahmodu-Tijani, Lateef. (2019). Vote Trading in Nigeria Politics. Asian People Journal (APJ), 2(2), 42-51.

Dovi, Suzanne. (2006). Political Representation.

Engelen, Bart. (2007). Why Compulsory Voting can Enhance Democracy. Acta politica, 42(1), 23-39. https://doi.org/10.1057/palgrave.ap.5500167

Jensen, P. Sandholt., \& Justesen, Mogens. K. (2014). Poverty and Vote Buying: Survey-Based Evidence from Africa. Electoral studies, 33, 220-232. https://doi.org/10.1016/j.electstud.2013.07.020

Onuoha, Freedom. C., \& Ojo, Jide. (2018). Practice and Perils of Vote Buying in Nigeria's Recent Elections. conflict trends, 2018(3), 21-29.

Onwuama, E. Michael. (2019). Impact of Poverty on Political Choices in the 2019 Nigeria General Election.

Sakariyau, Rauf. T., Aliu, F. Lawal., \& Adamu, Muhammed. (2015). The Phenomenon of Money Politics and Nigeria's Democratization: An Exploration of the Fourth Republic. Journal of Social Economics Research, 2(1), 1-9. https://doi.org/10.18488/journal.35/2015.2.1/35.1.1.9

Stober, E. Olusegun. (2016). Stomarch Infrastructure: Lessons for Democracy and Good Governance. Management Dynamics in the Knowledge Economy, 4(3), 449-460.

Stokes, Susan. C., Dunning, Thad., Nazareno, Marcelo., \& Brusco, V. (2013). Brokers, Voters, and Clientelism: The Puzzle of Distributive Politics: Cambridge University Press.

Weßels, B. (2015). Political Representation and Electoral Systems. In Oxford Research Encyclopedia of Politics. https://doi.org/10.1093/acrefore/9780190228637.013.76

Daily Post Newspaper.

Oxford Advance Dictionary ( $6^{\text {th }}$ edition).

Punch Newspaper, $14^{\text {th }}$ July, 2018

Punch Newspaper. $26^{\text {th }}$ October, 2018.

Sahara Reporter. $18^{\text {th }}$ July, 2018.

Received on 25-05-2021

Accepted on 14-07-2021

Published on 15-09-2021

https://doi.org/10.6000/1929-4409.2021.10.156

(C) 2021 Ilori Oladapo Mayowa; Licensee Lifescience Global.

This is an open access article licensed under the terms of the Creative Commons Attribution License (http://creativecommons.org/licenses/by/4.0/) which permits unrestricted use, distribution and reproduction in any medium, provided the work is properly cited. 